\title{
HOUSING AND INTEGRATING REFUGEES: SOUTH AFRICA'S EXCLUSIONARY APPROACH
}

\author{
Callixte Kavuro \\ LLB LLM LLD \\ Lecturer, Department of Public Law and \\ Jurisprudence, University of the Western Cape
}

\section{SUMMARY}

The article seeks to illuminate South Africa's exclusionary approach towards housing refugees and asylum seekers, and to integrating them into the economy. To this end, this article argues that the exclusionary approach conflicts with and is in violation of the constitutional values of human dignity, equality and freedom on which South Africa's refugee law is based. The article employs a qualitative research methodology to illustrate that policy issues are acting as barriers to accessing housing programmes. It makes recommendations on how to close the gaps in housing law to ensure that future planning and implementation of housing policies are in harmony with refugee policies. Finally, innovative and creative solutions to the challenges that refugees and asylum seekers face in the housing sector are drawn from the learning processes acquired from past experience.

\section{INTRODUCTION}

Under international refugee law, obligations imposed on South Africa include inter alia the extension of the fundamental rights and freedoms contained in the 1951 Convention Relating to the Status of Refugees (the Refugee Convention) to refugees and asylum seekers. Fundamental rights and freedoms include the right to have access to adequate housing. In this regard, article 21 of the Refugee Convention affirms:

"As regards housing, the Contracting States, in so far as the matter is regulated by laws or regulations or is subject to the control of public authorities, shall accord to refugees lawfully staying in their territory treatment as favourable as possible and, in any event, not less favourable than that accorded to aliens generally in the same circumstances."

It is self-evident that housing protection is founded upon three values that national governments must adhere or conform to in order to turn the right of access to housing into tangible entitlements. Those three values are: (i) equal treatment when compared to non-citizens in similar circumstances; (ii) lawful residence in the territory of the host state; and (iii) implementing the right in accordance with housing laws and regulations. It is within these 
parameters that the exclusionary approach to housing refugees in South Africa largely originates. Particular attention will be paid to the requirements of equal treatment and conformity to housing laws and regulations, given that documented asylum seekers and refugees are lawfully staying and residing in South Africa. ${ }^{1}$

The article presupposes that the question of housing refugees falls squarely within the mandate of the host state; hence, such host state is bound by article 21 of the Refugee Convention from which the three values mentioned above are drawn. ${ }^{2}$ For that reason, the standard of treatment of refugees and asylum seekers must be determined with reference to housing laws since housing rights of refugees must be enjoyed or accrued subject to regulations and the control of the local administration. ${ }^{3}$ From Da Costa's point of view, local administration is particularly obliged to "ensure that the relevant laws or regulations accord refugees the most favourable treatment possible, which should never fall below that granted to [non-citizens] generally". ${ }^{4}$ However, the implementation and interpretation of the right of access to housing in accordance with the three values contained in article 21 frustrates the right to housing of refugees in the South African legal system.

Against this background, the article, under heading two, delineates the impact and ramifications of the values postulated in article 21. It shows that these values, if interpreted strictly, work to justify and sustain the exclusion of refugees and asylum seekers in the housing development programmes provided under the Housing Act (as amended), ${ }^{5}$ the National Housing Code (as revised), ${ }^{6}$ and the National Housing Policy and Subsidy Programmes (NHPSP). ${ }^{7}$ The third part of this article substantiates the radical need for a shift from an exclusionary approach to an inclusive approach to ensure accessibility of adequate housing for refugees and asylum seekers. It demonstrates that other African countries apply an encampment policy whereby refugees and asylum seekers are housed in refugee camps. In addition, countries such as France and United States (US) offer housing assistance to refugees even though their respective constitutions do not

1 Van Reenen J, in Kiliko v Minister of Home Affairs 2006 (4) SA 114 (C), construed the stay of an asylum seeker in the context of lawful stay as follows:

"Section 22 of the Refugees Act ... allows the holder [of an asylum seeker permit] to sojourn in the Republic of South Africa, temporarily, subject to the conditions determined by the Standing Committee for Refugee Affairs ... In terms of section 22(3) ... such an officer is empowered to extend from time to time the period to which such a permit has been issued and also to amend the conditions subject to which it has been issued."

Weis The Refugee Convention, 1951 (1995) 163.

3 Da Costa Rights of Refugees in the Context of Integration: Legal Standards and Recommendations (2006) 68.

4 Ibid.

5107 of 1997, amended by the Housing Amendment Act 28 of 1999, the Housing Second Amendment Act 60 of 1999 and the Housing Amendment Act 4 of 2001.

6 The National Housing Code was published on 21 October 2000 in line with s 4 of the Housing Act and the revised National Housing Code was published in February 2009.

7 Department of Human Settlement "National Housing Policy and Subsidy Programmes" (February 2010) http://www.kzndhs.gov.za/Uploads/documents/Resource_Centre/ Legislation/National_Policies/National\%20Housing\%20Policy\%20and\%20Subsidy\%20Progr ammes.pdf (accessed 2018-04-01). 
contain socio-economic rights and benefits provisions. The fourth part sets out to illustrate that the exclusionary approach cannot be justified constitutionally. In this regard, it analyses whether the exclusion could be justified in terms of the constitutional limitations in section 26(2) of the Constitution. It finds the exclusionary approach to be irrational and unreasonable, since it is contrary to the constitutional objective of protecting human dignity and is in violation of the Refugees Act. ${ }^{8}$ The fifth part concludes by stressing the need to include refugees and asylum seekers in the housing development programmes and makes recommendations on how gaps in the law could be addressed to restore the dignity of refugees in a culturally and constitutionally sensitive manner.

\section{2 \\ ANALYSIS OF THE RIGHT IN THE CONTEXT OF THE ARTICLE 21 GUIDELINES}

\section{Equal treatment with non-citizens}

Section 6 of the Refugees Act requires the application of refugee rights (and their interpretation) to be in accordance with the international-refugee and human-rights standards and principles. The interpretation of the right of access to housing, considered in terms of international refugee law, acts as a barrier to the integration of refugees and asylum seekers into housing programmes. It is especially important to analyse the impact that the core standard of equal treatment has on the right of access to housing in the South African context. The core standard is conceived in terms of the notion that the treatment should be as favourable as possible and, in any event, not less favourable than that accorded to non-citizens who are generally in the same circumstances. ${ }^{9}$ In South Africa, no other non-citizens' circumstances are similar to those of refugees. Thus, difficulties in implementing or in claiming the right to housing arise from the absence of having other groups of non-citizens whose treatment concerning housing should serve as a yardstick for the favourable treatment of refugees. ${ }^{10}$

In the context of the Refugee Convention framework, the standard of equal treatment was incorporated as a viable mechanism of promoting favourable treatment of refugees and asylum seekers. It was introduced to end their exclusion from certain socio-economic rights and benefits and to ensure that every refugee or asylum seeker lawfully admitted and staying in the host country has equal rights in relation to socio-economic integration, particularly in relation to housing opportunities. ${ }^{11}$ Meeting the standard of equal treatment in the provision of housing becomes problematic in the South African context since the realisation of the core principle of equal

\footnotetext{
130 of 1998 , as amended.

Art 21 of the Refugee Convention.

The Constitutional Court confirmed this in Union of Refugee Women $v$ The Director, The Private Security Industry Regulatory Services 2007 (4) BCLR 339 (CC) par 108, when it stated that there are no non-citizens in the country "who are identically situated to refugees" on the sole basis that refugee status is unique in South African law.

11 Da Costa Rights of Refugees 68.
} 
treatment is reliant on the treatment afforded to other non-citizens generally in the same circumstances; but there is no such group of other noncitizens. $^{12}$

\section{In the same circumstances}

The notion of "in the same circumstances" also has the result of supporting the exclusion of refugees and asylum seekers from the housing development programmes provided for under South Africa's housing laws and regulations. The situation may be different in other countries, but in South Africa, this notion works to refugees' disadvantage. The reason for this is that there is no other category of non-citizens who are identically and similarly situated to refugees and asylum seekers for purposes of comparison. ${ }^{13}$ It is fundamentally important to understand how the notion "in the same circumstances" came about and how this notion has lost its legal weight and value in the South African legal system.

The standards concerning equal treatment and "in the same circumstances" contained in the Refugee Convention both have their roots in the principle of reciprocity. The according of certain socio-economic rights to refugees and asylum seekers should therefore be understood with reference to the standards in conditions of reciprocity. Between 1920 and 1950, favourable standards of treatment of refugees were viewed through the lens of reciprocity. This, in turn, was founded on the notion of placing citizens of state $A$, living in state $B$, in the same position in which state $A$ would place the citizens of state $B .{ }^{14} \mathrm{~A}$ bilateral agreement was therefore necessary to elucidate the reciprocal conditions of treatment of those non-citizens. It was this reciprocal treatment of citizens of two countries that served as the threshold basis of according refugees and asylum seekers similar rights to those enjoyed by citizens of the two countries in terms of the bilateral agreement. In this context, refugees and asylum seekers were to be treated as if they were in the same circumstances as those "favoured" non-citizens who were entitled to special reciprocal treatment. As Weis succinctly puts it, the principle of reciprocity was extended to refugees in order to guard against the possibility of placing refugees in an "unjustifiable position of inferiority with respect to other foreigners" or to guard against any possible request made by refugees "for special protection enjoyed by some noncitizens under the condition of reciprocity". ${ }^{15}$ The conditions of reciprocity have gradually disappeared; the application of fundamental human-rights standards and practices has culminated in all countries enacting immigration laws and policies based on the concepts of contribution and self-sufficiency. Contribution and self-sufficiency approaches are the cornerstones of South

12 Union of Refugee Women $v$ The Director, The Private Security Industry Regulatory Services supra par 107-110.

13 See the judicial opinions of Mokgoro and O'Regan JJ in Union of Refugee Women $v$ The Director, The Private Security Industry Regulatory Services supra par 107-110.

14 Weis The Refugee Convention, 1951 47-48.

15 Weis The Refugee Convention, 195148. 
Africa's immigration laws and policies. ${ }^{16}$ Based on the idea that South Africa should benefit from immigration, immigration laws and regulations were designed to include the admission of non-citizens who possess critical skills, investment, or both, implying that those with skills or capital can be admitted into the country. This approach bars non-citizens from being admitted into the country if they are unable to support themselves, if they have no critical skills that can support economic growth or if they possess no high-level capital to invest in the country for economic development. In other words, the approach implies that the general treatment of non-citizens excludes them from entitlements such as socio-economic rights and the benefits enjoyed by citizens through governmental subsidised programmes such as, social assistance, social housing, free healthcare services, and tertiary student financial assistance, to name but a few.

The main concern is that the disappearance of the conditions of reciprocity has resulted in there being no group of non-citizens to whom the right to housing applies based on reciprocity. Therefore, there are no favoured non-citizens whose treatment can serve as a yardstick against which to compare, claim, or scrutinise the standard of equal treatment as envisaged by the Refugee Convention. This is because the human-rights paradigm introduced the minimum standards of treatment that apply to all regardless of their nationality. At domestic level, the minimum standards of treatment are (or general treatment of non-citizens is) expounded under immigration laws and regulations.

Viewed through an immigration lens, applying the standard of "equal treatment with non-citizens generally in the same circumstances" implies that asylum seekers should be admitted into the country subject to the principles of contribution and self-sufficiency - that is, having the ability to satisfy their own needs and to contribute to South African economic development. Within this context, South Africa has invested all its energy and resources into controlling and managing non-citizens (including refugees) into contributing to its economic growth. ${ }^{17}$ From a self-sufficiency perspective, South Africa assumes that refugees and asylum seekers are capable of meeting their own socio-economic needs, including housing. Hence, they are offered no state support to promote their integration. ${ }^{8}$ South Africa appears to have adopted the contribution and self-sufficiency approaches and applies them to the right to have access to socio-economic rights and benefits, including the right to refugee housing. In adopting such approaches, it thus disregards the fact that asylum seekers' socio-economic conditions are different from that of other non-citizens. They are not in the same circumstances as other non-citizens generally. From the outset, they are admitted into the country on humanitarian grounds, being the inherent basis for the protection of refugees. ${ }^{19}$ This is recognised under section 23 of

16 See for eg, South Africa's Immigration Act 13 of 2002, in particular, s 11 (visitor's visa), s 15 (business visa), s 17 (medical treatment visa), s 18 (relative's visa), s 19 (work visa), s 20 (retired person visa) and s 21 (corporate visa).

17 Department of Home Affairs Annual Performance Plan 2018/19 (2018) 6.

18 Minister of Home Affairs $v$ Watchenuka [2004] 1 All SA 21 (SCA) par 32.

19 Preamble of the Refugee Convention. 
the Immigration $\mathrm{Act}^{20}$ which allows asylum seekers to enter the country without satisfying authorities that they were granted visas or possess sufficient means to support themselves. ${ }^{21}$ This demonstrates that South Africa, somehow, recognises that asylum seekers are not in the same economic or emergency circumstances as other non-citizens.

The protection of refugees' right to housing, based on equal treatment with non-citizens in the same circumstances, is problematic since South Africa often adopts immigration measures that restrict non-citizens - in particular, temporary residents - from having access to positive entitlements that give effect to socio-economic rights and benefits. ${ }^{22}$ Immigration laws are enacted and reviewed for the purpose not only of managing and controlling the flow of immigration, but also to safeguard and preserve national resources, materials and opportunities. ${ }^{23}$ This is achieved through the dual rule of contribution and self-sufficiency. Viewing refugees and asylum seekers through the lens of this rule, they cannot claim the constitutional right to have access to adequate housing, which is largely enforced through subsidised housing development programmes that aim to improve the quality of life of poor citizens and, to a certain degree, that of poor permanent residents.

\section{Conformity to housing laws and regulations}

The right to have access to adequate housing is, firstly, guaranteed by the Constitution and, secondly, is given effect and substance to by the Housing Act. ${ }^{24}$ The right of access to housing is further espoused under housing regulations such as the 2000 National Housing Code and the NHPSP. These housing laws and regulations render operational sections 26(1) and 28(1)(c) of the Constitution. Whereas section 26(1) states that "everyone has the right to have access to adequate housing", section $28(1)(c)$ states that every child has the right to shelter. It is therefore clear that housing laws and regulations were essentially enacted to "provide for the facilitation of a sustainable housing development process" financed by the State. ${ }^{25}$ In particular, housing rules establish the generic qualifying criteria for beneficiaries wishing to access state-funded housing programmes, and create the housing protection that has contributed substantively and positively to the improved position of historically disadvantaged groups whose fundamental rights to have adequate access to land and housing were unattainable during the apartheid regime. ${ }^{26}$

\footnotetext{
13 of 2002.

$\mathrm{S} 23$ stipulates that an asylum transit visa must be issued to "a person who at a port of entry claims to be an asylum seeker, valid for a period of five days only, to travel to the nearest Refugee Reception Office in order to apply for asylum".

22 Kavuro "Refugees and Asylum-Seekers: Barriers to Accessing South Africa's Labour Market" 201519 Law, Democracy and Development 232249.

23 Kavuro 2015 Law, Democracy and Development 249.

$24 \quad 107$ of 1997.

25 Long Title of the Housing Act.

26 Van der Walt "Exclusivity of Ownership, Security of Tenure, and Eviction Orders: A Model to Evaluate South African Land-Reform Legislation" 20022 TSAR 254265.
} 
However, the main concern remains that the housing framework is engineered to address the housing problems of citizens and permanent residents to the exclusion of temporary residents. ${ }^{27}$ This approach is rooted in the rules and principles of the Immigration Act that require temporary residents to be self-reliant and self-supportive. It is therefore presumed that, as temporary residents, refugees and asylum seekers are not allowed to have access to adequate housing.

The reservation of access (to the housing development programmes) for only those who are citizens and non-citizens with permanent residence is, firstly, reflected in the definition of "housing development" in the Housing Act, where it is said to mean "the establishment and maintenance of habitable, stable and sustainable public and private residential environments ... in which all citizens and permanent residents of the Republic will on a progressive basis have access to permanent residential structures" ${ }^{28}$ Secondly, the restriction is reflected in the 2000 National Housing Code and the NHPSP. Citizenship and permanent residence status are primary requirements to be able to apply for or receive individual subsidies, consolidation subsidies, institutional subsidies and rural subsidies and to be integrated into residential development programmes. ${ }^{29}$ Thirdly, the restriction is rooted in the ANC's Reconstruction and Development Programme of 1994 (RDP). The RDP, which strives to provide "citizens with a permanent residential structure with secure tenure, potable water, adequate sanitation facilities, and domestic energy supply", posits citizenship and permanent resident status as requirements for access to subsidised housing programmes. $^{30}$

The exclusion of refugees and asylum seekers from benefitting from these housing programmes is constitutionally problematic in that they are denied housing protection designed to provide poor and vulnerable people with privacy and to protect their well-being, dignity and family unity. The lack of protection of refugees and asylum seekers' housing needs results in their living in intolerable housing conditions, which contributes to their moral and social decline and exacerbates their past and present traumatic and distressful experiences. Exclusion is inimical and contrary to the constitutional pluralistic approach. It has been demonstrated that the Constitution does not, under sections 26(1) and 28(1)(c), reserve the right of access to housing for citizens alone, as these provisions explicitly refer to "everyone" and "every child". More fundamentally, by referring to the rights in the Bill of Rights, South Africa's obligation to accommodate refugee and

27 See the NHPSP par 1.2, 6.2, 8.2, 9.2 and 15.2 stating that citizens and permanent residents can benefit from the Integrated Residential Development Programme, the Institutional Housing Subsidy Programme, the Individual Subsidy Programme, the Rural Housing Programme and the People's Housing Process.

28 S 1(vi) of the Housing Act 107 of 1997.

29 These different types of housing subsidies are governmental housing programmes falling under the National Housing Subsidy Scheme (NHSS) to which the revised 2000 National Housing Code and the NHPSP apply; see Tissington A Resource Guide to Housing in South Africa 1994-2010: Legislation, Policy, Programmes and Practice (2011) 22.

30 Greyling The RDP Housing System in South Africa (B Sc (Hons) Quantity Surveying thesis, University of Pretoria) 200910 (in respect of RDP houses). 
asylum-seeker adults and children manifests itself in sections $27(b)$ and $27 \mathrm{~A}(d)$ of the Refugees Act. ${ }^{31}$ These two provisions entitle refugees and asylum seekers to the pluralistic constitutional rights and freedoms.

\section{The interpretational error of refugee rights}

Although the Refugees Act posits refugees and asylum seekers as beneficiaries of pluralistic constitutional rights and benefits, the government of South Africa erroneously or paradoxically justifies the exclusion of refugees and asylum seekers on the basis that they are temporary residents. Asylum seekers are admitted into the country as temporary residents and once they are formally recognised as refugees, they remain temporary residents. As temporary residents, they are excluded from rights, benefits and privileges that the law or policy extends to include non-citizens with permanent resident status. ${ }^{32}$ In principle, refugees and asylum seekers are eligible to apply for permanent residence if they have stayed in the country for a period of five years. ${ }^{33}$ However, as temporary residents, section 10(1), read together with section 10(4) of the Immigration Act, ${ }^{34}$ subjects them to the dual principles of contribution and self-sufficiency within the immigration framework. It is within the context of this dual-principles framework that South Africa interprets and applies refugee rights.

Emphasis on the exclusion of refugees and asylum seekers is given precedence when attempting to manage immigration securely and effectively in support of national development and security. ${ }^{35}$ Exclusion can furthermore be linked to South Africa's fear and anxiety that refugees and asylum seekers may place an impermissible burden on the state purse if allowed access to the welfare scheme. For this reason, South Africa, in 2016, introduced a Bill amending the Refugees Act. The purpose of this amendment was, inter alia, to authorise the assessment of asylum seekers' abilities to sustain themselves and their dependants, with the assistance of family or friends, for a period of at least four months or, alternatively, to assess whether they possessed skills needed by the country. ${ }^{36}$ Parliament adopted the Bill, which the President subsequently signed into law in $2017 .^{37}$ In implementing these new regulations, it is, however, not clear whether South Africa will close its border to indigent asylum seekers or asylum seekers who lack critical skills. It should be borne in mind that the Refugees Act reflects a self-integration and self-settlement policy as the Act does not impose any obligation on South Africa to promote integration, self-reliance or participation and agency of refugees and asylum seekers through state-

\footnotetext{
130 of 1998

32 Refugees and asylum-seekers cannot access certain rights on the sole basis that they are neither citizens nor permanent residents; see Union of Refugee Women $v$ The Director, The Private Security Industry Regulatory Services supra par 42, 55, 65.

33 S 27(c) of the Refugees Act 130 of 1998.

$34 \quad 13$ of 2002.

35 Department of Home Affairs Annual Performance Plan (2018) 613.

$36 \mathrm{~S} 22(6)-(7)$ of the Refugees Act as amended by $\mathrm{s} 18$ of the Refugees Amendment Bill [B12-2016].

37 The Refugees Amendment Act 11 of 2017.
} 
funded mechanisms. Refugees and asylum seekers must fend for themselves and their families.

\section{Political justifications of the exclusionary approach}

Exclusion of refugees in social welfare schemes is morally justified based on the political belief that South Africa's resources should only be distributed to improve the quality of life of citizens, especially those who were historically disadvantaged. ${ }^{38}$ This political position is advanced and advocated on the understanding that although refugees are vulnerable, apartheid policies did not disadvantage them. It is further argued that they are "not taxpayers." 39 Politically, they are portrayed as "bogus refugees" who are in the country in search of a better life; ${ }^{40}$ and as human parasites or economic migrants who will drain the national resources. ${ }^{41}$ Portraying them as economic migrants sends a severe message to citizens that refugees and asylum seekers are in the country to take employment, business and social assistance opportunities away from them, thus discounting completely the fact that they are in the country because of a well-founded fear of persecution and flagrant human-rights abuse in their home countries. ${ }^{42}$ The South African government has therefore made efforts to restrict refugees and asylum seekers from accessing socio-economic rights and benefits. Such efforts are reflected in the numerous amendments to the Refugees Act, which aims to limit their rights even further. ${ }^{43}$

38 Kavuro 2015 Law, Democracy and Development 249-252; see too De Vos "Looking Backwards, Looking Forward: Race, Corrective Measures and the South African Constitutional Court" 201279 Transformation: Clinical Perspective on Southern Africa 144 144-167.

39 Gunn and Tal Torn Apart: Thirteen Refugees tell their Stories (2003) 16.

40 Landau "Protection and Dignity in Johannesburg: Shortcomings of South Africa's Urban Refugee Policy" 200619 Journal of Refugee Studies 308 316; and Danso and McDonald "Writing Xenophobia: Immigration and Print Media in Post-Apartheid South Africa" 200148 Africa Today 115119.

41 See for eg, Danso and McDonald 2001 Africa Today 116 (they are responsible for stealing opportunities and causing crime and diseases); Landau and Manson "Displacement, Estrangement and Sovereignty: Reconfiguring State Power in South Africa" 200843 Government and Opposition 315322 (refugees will multiply and increase the South African population and in future, citizens will suffer); Neocosmos "The Politics of Fear and the Fear of Politics: Reflection on Xenophobic Violence in South Africa" 200843 Journal of Asian and African Studies 586589 (migrants come to South Africa to take and not contribute anything); and Adepoju "Continuity and Changing Configuration of Migration to and from the Republic of South Africa" 200341 International Migration 3 9-18 (a direct threat to citizens' future economic well-being).

42 Khan Patterns and Policies of Migration in South Africa: Changing Patterns and the Need for a Comprehensive Approach Paper drafted for discussion on Patterns on Policies of Migration (2007) www.refugeerights.uct.ac.za/patterns_policies_migration_FKhan.html 10 (accessed 2017-06-12); also see Kofman "Rights and Citizens" 199325 American Sociology Review 393395.

43 By the Refugees Amendment Act 33 of 2008; the Refugees Amendment Act 12 of 2011, and the Refugees Amendment 11 of 2017; see too Kavuro "South Africa's Refugee Policy: New Grounds to Exclude Refugees from Refugee Protection" (2017) Rights in Exile http://rightsinexile.tumblr.com/post/159067508272/south-africas-refugee-policy-newgrounds-to (accessed 2018-02-10). 
 \\ ARGUMENTS FOR THE INCLUSIVE APPROACH}

\section{The comprehensive objective of refugee protection}

Offering refugees and asylum seekers a safe haven to stay and integrate into society, with a view to restoring normalcy to their lives, are essential to ensure their safety and security and emancipate them from persecution and human-rights abuses. As a prerequisite to dealing with their past and present (often-traumatic) suffering, the dignity of refugees must be restored in a culturally sensitive manner. If a particular state offers a safe haven, it must be offered in conjunction with effective asylum protection. Effective protection of persecuted, abused and oppressed people comes with international obligations to accord fundamental human rights and freedoms as contemplated by the Refugee Convention and human rights treaties. ${ }^{44}$ South Africa acknowledged its international obligations when it ratified the Refugee Convention and transposed it into its legal system through the Refugees Act as required by sections 231(2) and 231(4) of the Constitution. In doing so, it domesticated the international obligations so that they became national and constitutional requirements.

Nevertheless, obligations exist in South Africa's refugee law to offer housing protection to refugees and asylum seekers in order to ensure that they are not left without a roof over their heads. Of specific importance is that refugees or asylum seekers are people who were forced to leave their homes and, as a result, have become homeless. They are people in an emergency situation and their refugee status must be responded to by offering humanitarian relief and assistance such as adequate food, adequate clothing, adequate water, medical services and shelter. At the heart of the matter is the sense that a refugee or asylum seeker should no longer be homeless if offered asylum protection. They should be offered a private place to call their home away from home. Having a home is an essential aspect in everyone's life. It is fundamentally important to understand that a home is a tool that offers privacy and fosters a dignified family life. It is a private place - a physically defined area - where family life, family unity, moral values, and societal norms develop. ${ }^{45} \mathrm{~A}$ better home or adequate housing is viewed as a sine qua non for a better standard of living that supports the health and well-being of an individual and his or her family. This finds particular expression in article 21(1) of the 1948 Universal Declaration of Human Rights and article 11 of the 1966 International Covenant on Economic Social and Cultural Rights. It is viewed as a basis for the establishment of a just and equitable world economic order under Habitat ${ }^{46}$

44 When the Refugee Convention was enacted, the international community had a profound concern to ensure refugees and asylum seekers were accorded "the widest possible exercise of these fundamental rights and freedoms" as declared by the 1945 Charter of United Nations and espoused by the 1948 Universal Declaration of Human Rights. See the Preamble of the Refugee Convention.

45 Moreno Gómez $v$ Spain (Application No. 4143/02, ECHR 2004-X) Judgment of 16 November 2004 par 53.

46 See Preamble, read with art 1 of the Vancouver Declaration on Human Settlements (Habitat I) (adopted on 31 May to 11 June 1976) A/CONF.70/15. 
and as a basis of sustainable human settlements development under Habitat II. ${ }^{47}$ Considered from this perspective, the provision of adequate housing to refugees and asylum seekers serves to promote their integration - not only in the host society - but also in the host society's socio-economic progress and prosperity. Evidently, providing adequate housing is an important element of empowering refugees and asylum seekers to participate in local activities. This obligation is particularly reflected in the 1981 African Charter on Human and Peoples' Rights (African Charter), which imposes an obligation on the State to create "a general satisfactory environment favourable to [all peoples'] development and to assist and support the family to take care of its physical health and morals". ${ }^{48}$ It follows that providing housing is necessary not only to enhance the freedom of the people to participate in and benefit from local socio-economic integration and development, but also to contribute to their freedom to develop their human capabilities to live their life according to their choices. It is against this background that the article turns to explore the manner in which other countries protect the right to housing in order to learn some lessons from their experiences.

\section{African countries' approach}

Integrating refugees and asylum seekers into housing programmes is one of the greatest challenges facing host African countries since it is difficult for them to guarantee the right to housing for their own citizens, let alone for refugees and asylum seekers. Housing problems are critical, and the matter is usually dealt with by prioritising vulnerable peoples' needs in general and giving special attention to their circumstances in particular. Since many African countries are experiencing tremendous social and economic hardships, asylum protection consists mostly of an encampment policy, implying that housing protection is restricted to allowing for refugee camps, where refugees are housed in makeshift tents. ${ }^{49}$ Protecting refugees under a refugee camp programme as a matter of course excludes refugees and asylum seekers from claiming equal access to national housing development programmes. In the refugee camps, the duty to ensure privacy, safety and security of refugees by means of housing is discharged in collaboration with the United Nations High Commission for Refugees (UNHCR) and other international agencies cooperating with local authorities. ${ }^{50}$ It is argued that by accommodating refugees in makeshift tents, they are afforded a roof over their heads.

Unlike other African countries, South Africa historically has applied a nonencampment policy. It views an encampment policy as socially negative and

47 Istanbul Declaration on Human Settlements (Habitat II) (adopted on 7 August 1996) UNA/CONF $165 / 14$ par 1.

48 Art 18(1)-(2) of the African Charter.

49 The Addis Ababa Document on Refugees and Forced Population Displacement in Africa 8-10 September 1994 par 13.

50 Hathaway The Rights of Refugees under International Law (2005) 471. 
likely to "create serious logistical, security and humanitarian problems". 51 Non-encampment-based refugee protection is designed to be implemented through the extension of the application of the pluralistic rights in the Bill of Rights to refugees and asylum seekers. ${ }^{52}$ However, this protection is hindered by interpreting refugee rights through the lens of immigration rules and principles as explained above.

Under the Refugees Amendment Bill of 2016 (2016 Bill) and the Green Paper on International Migration of 2016 (2016 Green Paper), South Africa intends to apply an encampment policy to accommodate asylum seekers. Both the 2016 Bill and the 2016 Green Paper introduce Processing Centres that will be established closer to the border. ${ }^{53}$ These centres would accommodate asylum seekers during their status determination process. The UNHCR and charity organisations, in particular, the Red Cross, would be tasked with funding these centres. ${ }^{54}$ Placing the responsibility to house asylum seekers on the UNHCR is evidence enough that South Africa is not willing to deploy its resources for effective refugee protection. Confirmation of this can further be drawn from the fact that the 2016 Green Paper is silent on whether those who are (or will be recognised as) formal refugees will be included in social housing programmes. It simply states that adequate mechanisms will be established to ensure that refugees are fully integrated into communities and that the relevant state and civil institutions will support and coordinate these mechanisms.

\section{European Union approach: France}

In contrast to South Africa, the right to housing is not expressly contained in the French Constitution. However, the European Union has defined certain obligations to harmonise the conditions of asylum seekers across Europe, including standardising housing conditions. ${ }^{56}$ In particular, article $3(1)(\mathrm{h})$ of the 2000 Council Directive ${ }^{57}$ requires European countries to implement the principle of equal treatment between persons, irrespective of racial or ethnic origin. This guiding principle stipulates that equal treatment shall specifically "apply to all persons, as regards both the public and private sectors, including public bodies, in relation to [...] access to and supply of goods and services which are available to the public, including housing". Noting that no duty exists under the French Constitution to provide for socio-economic rights and benefits, the Constitutional Council has nevertheless emphasised

51 Department of Home Affairs: Green Paper on the International Migration, GN XXX GG 1 of 24 June 2016 (the 2016 Green Paper) 67.

52 Ss 27(b) and 27(c) of the Refugees Act 130 of 1998.

53 The 2016 Green Paper 65; see too $\mathrm{cl} 18$ of the Refugees Amendment Bill [B12-2016], which wholly substituted s 22 of the Refugees Act, which was amended by s 15 of the 2008 Refugees Amendment Act.

54 The 2016 Green Paper 65 67; see too cl 18 of the 2016 Refugees Amendment Bill.

55 The 2016 Green Paper 65.

56 Council Directive 2003/9/EC, Laying Down Minimum Standards for the Reception of Asylum Seekers, 2003 OJ L 031.

57 Council Directive 2000/43/EC of 29 June 2000 implementing the principle of equal treatment between persons irrespective of racial or ethnic origin, OJ L 180, 19.7.2000. 
that Parliament is obliged to reconcile refugee rights, set forth under refugee treaties or agreements, with the constitutional principles of individual freedom and family life. ${ }^{58}$ In this context, article L744-6 of the Code de l'Entrée et du Séjour des Étrangers et du Droit d'Asil (CESEDA) ${ }^{59}$ establishes a legislative mandate entrusted with the French Office of Immigration and Integration (or, in French, Office Français de l'Immigration et de I'Intégration) (FOII) to assess the material needs and social vulnerabilities of asylum seekers within a reasonable time. The assessment includes a determination of special protections to be accorded to different categories of asylum seekers, such as non-accompanied minors, people with disabilities, the elderly, people with serious diseases, and mentally ill persons. ${ }^{60}$

Article L744-3 of CESEDA states that asylum seekers are accommodated under the state-funded reception centres managed by the FOII. In this regard, France has adopted a refugee housing policy in terms of which refugee accommodation has been established throughout the country. The right to housing is normatively viewed as a component of the right to public relief and assistance. On this basis, genuine asylum seekers are housed at Processing Centres, known as the Centres d'Accueil pour Demandeurs d'Asile (CADA). ${ }^{61}$ The CADA prioritise the housing needs of families with children $^{62}$ and single asylum seekers have access to emergency accommodation. ${ }^{63}$ Emergency accommodation is available to asylum seekers at night, if they have booked it, but it does not provide a meal. ${ }^{64}$ Upon being recognised as refugees, asylum seekers have the right to remain in the CADA for three months from the date on which refugee status was granted. However, the period of three months can be renewed once, subject to agreement by the local authorities. Once recognised as a refugee, an individual is eligible to apply for residence at a temporary accommodation centre and, alternatively, in social housing. ${ }^{65}$ Social housing becomes perpetual once allocated to a refugee. ${ }^{66}$

58 Constitutional Council, Decision 92-307 DC of 25 February 1992, par 8-9.

In English: the Code of Entry and Stay for Foreigners and the Right to Asylum.

Art L744-6 of CESEDA.

61 Maastricht Treaty on European Union, February 7 1992, OJ (C191) (1992) 31 ILM 247 (1992), as amended by the Treaty of Amsterdam, October 2 1997, OJ (C340) (1997); and the regulations of the Council of the European Union of 18 February 2003 (Dublin II Regulations) 10.

62 Freedman Female Asylum-seekers and Refugees in France Unpublished paper prepared for Legal and Protection Policy Research Policy Series, PPLAS/2009/0 36, (June 2009) (http://www.refworld.org/pdfid/4a535e112.pdf) 36.

63 Freedman Female Asylum-seekers 45.

64 Ibid.

65 Dublin II Regulations 17.

66 International Federation for Housing and Planning (IFHP) "Housing Refugees Report" (2015) http://www.ifhp.org/sites/default/files/staff/IFHP\%20Housing\%20Refugees\%20 Report\%20-\%20final.pdf (accessed 2017-10-13) 16. 


\section{The American approach: US}

Like France, the Constitution in the US does not guarantee the right to housing and accommodation. Moreover, the Refugee Act of $1980^{67}$ does not expressly protect the right to have access to adequate housing. However, this does not absolve the US from protecting refugees' access to adequate housing. The concern to protect the housing needs of refugees is reflected in the Refugee Protection Bill of $2013,{ }^{68}$ which amends the Immigration and Nationality Act of $1952 .^{69}$ It establishes a mandate for collecting data relating to the housing needs of refugees, including (i) the number of refugees who have become homeless; and (ii) the number of refugees at severe risk of becoming homeless. ${ }^{70}$ This indicates that the US is concerned with responding to the housing needs of those who are formally recognised as refugees.

Despite the absence of constitutional protection for socio-economic needs, the US is committed to integrating refugees into its local communities. In the US context, integrating refugees is understood as "a dynamic, multidirectional process in which new comers and the receiving communities intentionally work together, based on a shared commitment to tolerance and justice, to create a secure, welcoming, vibrant, and cohesive society". ${ }^{71}$ The integration process is based on eight factors, including, inter alia, health (or well-being), language, economic opportunity, civic values (or participation or engagement), education, housing, social connections, and belonging (or safety). ${ }^{72}$ Social benefits to realise these factors are provided on a short-term basis since the US has no long-term integration policy in place. Its current integration policy is based on the provision of "limited, timebound assistance aimed at meeting the immediate needs of the refugees". 73 The housing required for those formally recognised as refugees is provided in terms of resettlement processes. These processes have the consequence of depriving asylum seekers of opportunities to be provided with socioeconomic support or basic social housing benefits.

In practice, asylum seekers arriving at the US borders are housed in detention centres, pending determination of their credible fear of returning to their home country. ${ }^{74}$ Expedited expulsion, removal or deportation is applied to those individuals who cannot establish such credible fear. ${ }^{75}$ Asylum seekers, admitted on the basis of meeting immigration policy conditions, are

\footnotetext{
(P.L. 96-212-Mar, 17, 1980).

(S 645 IS)

(8 U.S.C. 1181).

S 28(b) of the Refugee Protection Act of 2003 (S 645 IS).

Dawyer Refugee Integration in the United States: Challenges and Opportunities (2010) 12.

Dawyer Refugee Integration 13.

Dawyer Refugee Integration 15.

Human Rights First "U.S. Detention of Asylum-Seekers Seeking Protection, Finding Prison" April 2009-Revised June 2009.

75 Wasem "U.S. Immigration Policy on Asylum-seekers" 2005 SCR Report for Congress 1, 1.
} 
not entitled to have access to welfare schemes, including housing. ${ }^{76}$ In very limited and exceptional circumstances, they may have access to special federal benefits under the immigration policy. These special federal benefits, which include short-term shelter or housing assistance, are normally accorded to vulnerable indigent migrants. ${ }^{77}$ It can therefore be inferred that the US's asylum law lags behind others with regard to the protection of asylum seekers. Only refugees are assisted to integrate into and resettle in society and the integration policy includes the provision of housing as a foundation of facilitating self-sufficiency and self-reliance. The 1980 Refugee Act obliges the US to promote local integration as a mechanism to find durable solutions to refugee problems. ${ }^{78}$

4

UNCONSTITUTIONALITY OF THE EXCLUSIONARY APPROACH

\section{Breach of constitutionalised international obligations}

Domestically, South Africa is obliged to protect the right to housing of refugees by virtue of sections $27(b)$ and $27 \mathrm{~A}(d)$ of the Refugees Act, read with sections 26(1) and 28(1)(c) of the Constitution. Section 27(b) states that refugees are "entitled to full legal protection, which includes the rights set out in [the Bill of Rights], except those rights that only apply to citizens". Furthermore, section $27 \mathrm{~A}(d)$ states that asylum seekers are entitled to "the rights contained in the Constitution of the Republic of South Africa, 1996, in so far as those rights apply to an asylum seeker". The rights that apply to an asylum seeker must be understood to refer to those rights in the Bill of Rights that apply to everyone; no rights in the Constitution apply specifically to asylum seekers only. Save for the right to have access to land, ${ }^{79}$ everyone is constitutionally entitled to all other socio-economic rights, including adequate housing. ${ }^{80}$

Arguably, South Africa's exclusionary approach is inconsistent with the Constitution and the Refugees Act. In the context of transformative constitutionalism, section 26 (in particular) imposes obligations on the State

76 Human Rights Watch "At Least Let Them Work" (12 November 2013) https://www.hrw.org/ report/2013/11/12/least-let-them-work/denial-work-authorization-and-assistance-asylumseekers-united (accessed 01-04-2018-04-01) 45.

77 S 1611(b)(1)(D)-(E) of the United States Code Title 8: Aliens; Nationality and McBride "Migrants and Asylum-Seekers: Policy Responses in the United States to Immigrants and Refugees from Central America and Caribbean" 199937 International Migration 289292 and Human Rights Watch Human Rights Watch https://www.hrw.org/report/2013/11/12/ least-let-them-work/denial-work-authorization-and-assistance-asylum-seekers-united 31-32.

78 S 101(a) of the Refugee Act 1980, Public Law 96-212-Mar, 17, 1980.

79 S 25(5) of the Constitution states: "The state must take reasonable legislative and other measures, within its available resources, to foster conditions which enable citizens to gain access to land on an equitable basis."

80 These are rights to: housing, healthcare, food, water, social security, education, basic nutrition for children, and shelter for children. 
"to ensure that all people living in South Africa are able to satisfy all the requirements with regard to adequacy of housing". ${ }^{81}$ According to this principle, South Africa is obliged to take measures so as not to violate the constitutional and legislative right of refugees and asylum seekers to access adequate housing. At the forefront of efforts to address these inherent socioeconomic problems, South Africa must recognise that offering a safe haven to refugees also comes with the responsibility to respond to their socioeconomic needs in a sensible and equitable manner. Bearing this in mind, South Africa would be failing the international community if refugees and asylum seekers were excluded from housing development programmes. The reality is that exclusion from housing development programmes has a deleterious impact on refugees and asylum seekers' physical integrity as their humanity is thereby stigmatised and pathologised. Obviously, a material breach of sections 26(1) and 28(1)(c) is highlighted where a refugee or an asylum seeker is denied access to adequate housing or shelter, or where there is evidence of overlooking the housing needs of refugees or asylum seekers. In such situations, there is substantive evidence of the infringement of a range of constitutional rights such as equality, human dignity and security of the person, which are at the core of the notion of protection of humanity. In light of the preceding analysis, constitutional housing obligations should be interpreted widely to mean the transition to socio-economic transformation for the achievement of equal, dignified and secure living conditions for the homeless and those living in intolerable housing conditions, including refugees and asylum seekers. Essentially, housing programmes must be people-oriented in order to improve the conditions of vulnerable groups of people. ${ }^{82}$ Special attention should be paid to the particular circumstances and the housing needs of all vulnerable, disadvantaged people (whether they were disadvantaged by virtue of apartheid policies or political events occurring in their home countries) so as to improve the quality of their living. Depriving them of access to housing gives rise to serious violations of constitutional law, international refugee law and human rights law.

As noted above, adopting the Refugees Act, which, at its core, is informed by the constitutional objects and spirit to guarantee everyone's dignity, had the effect of constitutionalising and domesticating international obligations. Depriving a person of access to housing or shelter can most likely be seen as a flagrant violation of human dignity. Without access to housing, refugees and asylum seekers are deprived of: the right to an adequate standard of living, which is vital to their health and well-being; the right to their family life or unit, which is viewed as integral to individual and societal development; and the right to a conducive environment favourable to their privacy, physical integrity and family security. Denying the right to adequate housing is a deprivation of a core socio-economic right that is of vital importance for the realisation of economic, social and cultural integration and participation.

\footnotetext{
Tissington A Resource Guide to Housing 26.

2 lbid.
} 


\section{An analysis of constitutional limitations}

The salient question is whether the exclusion of refugees can be justified based on the limitations expressed in section 26(2) of the Constitution. These limitations are available resources and progressive realisation. ${ }^{83}$ The Committee on Economic, Social and Cultural Rights defined progressive realisation as imposing a substantive obligation on the State to move as "expeditiously and effectively as possible towards the goal of universal realisation of rights". ${ }^{84}$ Thus, any retrogressive measure has to be taken after a thorough consideration. ${ }^{85}$ This approach was reaffirmed in Government of the Republic of South Africa v Grootboom (Grootboom), ${ }^{86}$ when the Constitutional Court held that progressive realisation should be interpreted to mean the removal of a range of legal, administrative, operational, and financial obstacles that negatively impact on rights, and the expansion over time of such access to a larger and broader range of people. $^{87}$ Substantial justifications are required if retrogressive measures would result in depriving the homeless, poor and other vulnerable groups of access to adequate housing. ${ }^{88}$

In this context, the State must provide substantial justifications for why housing laws and policies do not include refugees and asylum seekers. It would be difficult to justify their exclusion based on progressive realisation in the face of the minimum obligations imposed by section 26(1). At a minimum, the Constitutional Court interpreted section 26(1) as imposing constitutional obligations on the State to take immediate steps to provide housing relief to those who are in urgent and desperate need and living in appalling and intolerable conditions. ${ }^{89}$ The Constitutional Court shifted the focus from quantifying the right to adequate housing with reference to a specific minimum core (or by providing everyone with an immediate basic level of housing) to quantifying the right to housing having reference to protecting everyone's dignity. A shift from the minimum core approach was justified on the moral understanding that different groups in different social settings have different housing needs in order to protect their dignity. ${ }^{90}$

At the same time, the Constitutional Court recognises that there are resource implications for the State when achieving the goal of housing its population and, by so doing, protecting their human dignity. There is consequently a need to balance the housing needs and the State's resource

83 S 26(2) provides: "The state must take reasonable legislative and other measures, within its available resources, to achieve the progressive realisation of this right."

84 General Comment No. 3: The nature of the States parties obligations: Article 2(1) of the International Covenant on Economic, Social and Cultural Rights E/1991/23 (1991) par 9.

85 Government of the Republic of South Africa v Grootboom 2000 (11) BCLR 1169 (CC) par 45, quoting the Committee's General Comment No. 3, par 9; see too Tissington A Resource Guide to Housing 28 and Liebenberg Socio-Economic Rights Adjudication under a Transformative Constitution (2010) 187.

87 Sar

Liebenberg Socio-Economic Rights Adjudication 189.

89 Government of the Republic of South Africa $v$ Grootboom supra par 52.

90 Par 30-39. 
capacity. ${ }^{91}$ Despite the financial constraints defence, the State must still adopt measures calculated to respond to housing needs in an expedited and effective manner. ${ }^{92}$ Besides, there is no reasonable justification for failing to respond to the housing needs of the most vulnerable groups in society, especially in situations where the State's failure arises from the absence of a comprehensive inclusive programme. ${ }^{93}$ Thus, the State's failure to reconcile the Refugees Act with its housing development programmes is difficult to justify based on lack of resources. Instead, the State bears the onus to demonstrate that it is doing its best within its available resources to provide refugees and asylum seekers with accommodation. Instead, the State has preferred to demonstrate that it is host to a high number of bogus refugees owing to the weaknesses in the asylum system and that it is concerned with catering for those bogus refugees who have abused the relatively simple asylum application process. ${ }^{94}$

It follows that exclusion from housing development programmes is usually justified based on the rationale of preserving national resources and material. However, the notion of preserving national resources need not be separated from the question of available resources. This is so because the question of preservation traverses the question of whether inclusion of (bogus) refugees and asylum seekers would impose impermissible financial burdens on the state purse. This argument was nevertheless rejected in an obiter dictum in Somali Association of South Africa v Limpopo Department of Economic Development Environment and Tourism. ${ }^{95}$ In this case, the Supreme Court of Appeal (SCA) stated that South Africa should work towards establishing an effective asylum system that will ensure that genuine refugees are recognised within a reasonable time and are fully protected. ${ }^{96}$ The SCA further held that the gaps in the asylum management process could not be used as a legitimate ground for the State to deviate from its constitutional obligations. ${ }^{97}$ Furthermore, the frustration experienced by the State, as it deals with a large number of asylum seekers and refugees, should not blind it to its constitutional and statutory obligations. ${ }^{98}$ Failure to meet the obligation of protecting refugees was held to be unacceptable and contrary to the constitutional values of human dignity, equality and freedom. ${ }^{99}$ The nature and extent of the exclusion of refugees from the right to housing on the basis of preservation of national resources and material may have the potential of compelling refugees and asylum seekers to live in perpetual homelessness, poverty, humiliation and degradation.

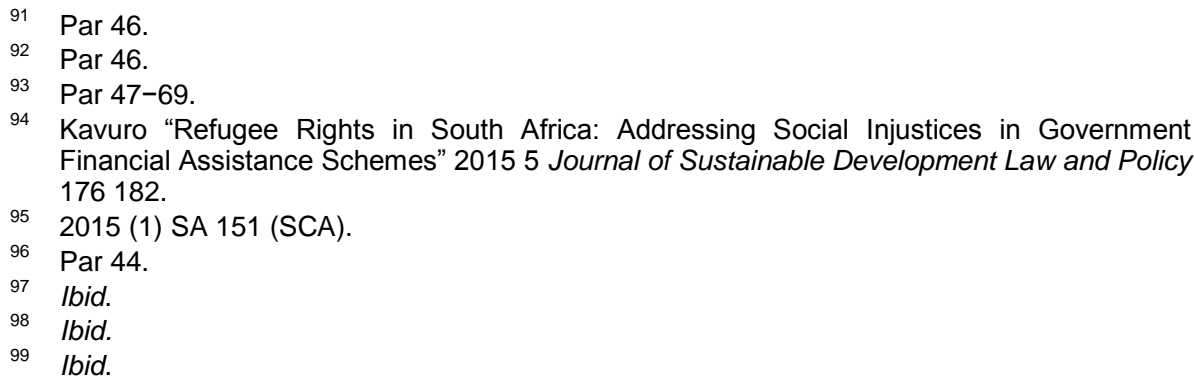


Taking into account the nature and extent of the impact of such exclusion, the Constitutional Court in Grootboom ${ }^{100}$ (dealing with emergency shelter) and in Khosa v Minister of Social Development, Mahlaule v Minister of Social Development (Khosa) ${ }^{101}$ (dealing with social security) reasoned that the State has no legitimate reasons to justify the exclusion of those in desperate need from any social welfare scheme on the basis of either budgetary constraints or preservation of resources if they are entitled to it in terms of law. In Khosa, the court took into account that the inclusion of permanent residents would not have vast budgetary implications ${ }^{102}$ and made it very clear that the decision to include non-citizens in social welfare schemes applied only to permanent residents since their legal position was similar to those of citizens in most respects. ${ }^{103}$ However, this article has demonstrated that refugees and asylum seekers should, in terms of the Refugees Act, be beneficiaries of socio-economic rights and benefits, including housing. What is not clear is the extent and scope of the financial implications.

Despite the potential financial implications involved, it is submitted that South Africa must also dedicate some of its energy and resources, according to its mandate arising from the Refugees Act, to protect refugees and asylum seekers. The mandate requires the State to provide for the rights and obligations flowing from refugee status, ${ }^{104}$ as well as from the Bill of Rights. ${ }^{105}$ Based on this premise, it would be unfair to construe the Housing Act ${ }^{106}$ as catering for citizens and permanent residents only; refugees and asylum seekers are also entitled to have access to social housing schemes put in place by the State to protect their dignity and health. In Union of Refugee Woman, ${ }^{107}$ the Constitutional Court noted with concern that it would always be difficult for the State to justify excluding refugees and asylum seekers (i) if the impugned right is a pluralistic constitutional right and (ii) if the Refugees Act (or any other statute) specifically confers the impugned right upon them. In particular, it becomes more difficult to justify exclusion in situations where such exclusion impairs the dignity of refugees and asylum seekers in a serious manner, ${ }^{108}$ or if it effectively condemns them to perpetual destitution and humiliation. ${ }^{109}$ Such exclusion cannot be

Supra.

2004 (6) SA 505 (CC).

102 The Chief Director of Social Services in the National Treasury provided evidence demonstrating that "the additional annual cost of including permanent residents ... could range between R243 million and R672 million. The possible range demonstrate[d] the speculative nature of the calculations, but even if they [were] taken as providing the best guide of what the cost [might] be, they [did] not support the contention that there [would] be a huge cost in making provision for permanent residents." See Khosa v Minister of Social Development, Mahlaule v Minister of Social Development supra par 62.

103 Par 59. Like citizens, permanent residents "have made South Africa their home" and also "owe allegiance of duty to the state".

104 Title of the Refugees Act.

105 S 27

$106 \quad 107$ of 1997 .

107 Union of Refugee Women v The Director, The Private Security Industry Regulatory Services supra par 46.

108 Par 113.

109 Somali Association of South Africa v Limpopo Department of Economic Development Environment and Tourism supra par 44. 
justified in terms of any provisions in either section 36 or section 9(5) of the Constitution. ${ }^{110}$ Subjecting refugees and asylum seekers to protracted deprivation of the right to housing has a serious impact on their human dignity and on their ability to live and participate fully in their host community.

5

\section{CONCLUDING RECOMMENDATIONS}

REMARKS

AND

South Africa should, firstly, not be seen to be contributing to the desperation of refugees or as deviating from its obligations to prevent or alleviate their suffering on the ground that it is applying the same-treatment approach. This approach activates and legitimises both the contribution and self-sufficiency approaches to the treatment of non-citizens, or claims that a large number of those seeking asylum in South Africa are "bogus" refugees. ${ }^{11}$ Secondly, if applications for asylum, after thorough consideration, have been accepted, it is immoral and unjustifiable to refer to the successful applicants as "bogus" refugees. It is also unconstitutional not to accord to them the differentiated treatment that the Refugees Act provides for. In offering them differentiated treatment, South Africa should bear in mind that it owes a duty of protection to these people. It also owes such a duty to the international community.

Thirdly, it has been demonstrated that the wide acceptance of protecting asylum seekers was motivated by a need to move away from stigmatising and pathologising refugees and towards a goal of alleviating their past and present human suffering. In South Africa, the right to have access to adequate housing can also be linked to the constitutional aspiration of alleviating human suffering by improving the quality of life for everyone. ${ }^{112}$ The provision of housing or shelter or accommodation lies at the heart of the founding values of South African society - namely, the achievement of dignified living in a free, democratic and equal society. The question of welcoming and protecting refugees and asylum seekers should be considered within the notion of achieving social justice for all through the advancement of individual freedoms. Fourthly, in dealing with refugees, it is especially important to understand their plight: refugees are people who came to South Africa to seek shelter, safety and security. These three aspects must be understood in terms of human rights protection particularly with regard to the protection of socio-economic rights such as housing, education, employment, social relief and assistance, healthcare, food and water. They will never feel safe and secure if they continue to live in intolerable and inhumane conditions.

Fifthly, if refugees and asylum seekers are afforded the same treatment accorded to non-citizens with regard to housing, they are effectively excluded from the housing development programmes. In order to

110 Union of Refugee Women $v$ The Director, The Private Security Industry Regulatory Services supra par 124.

111 Since 1998 to date, senior officials of Home Affairs have tended to argue that refugees are economic migrants. Accordingly, they are bogus refugees.

112 Government of the Republic of South Africa v Grootboom supra par 1. 
accommodate refugees and asylum seekers, the Housing Act $^{113}$ should not be interpreted in terms of the Immigration Act; ${ }^{114}$ rather it should be interpreted in terms of the Refugees Act. ${ }^{115}$ Thus, the Housing Act must be reconciled with the Refugees Act. The two values that are entrenched in article 21 of the Refugee Convention - that is, equal treatment and conformity to housing rules - work to disadvantage refugees and asylum seekers if interpreted in light of South Africa's laws regulating the stay of non-citizens generally. Under immigration law, non-citizens are required to be self-reliant and self-supportive. Under no circumstances can they rely on state support for their socio-economic needs, such as housing, food and medical attention. In contrast, refugee laws seek to move away from the requirement of self-reliance to a humanitarian approach grounded in the accessibility of public goods essential for the protection of refugees' health, dignity, safety and well-being. The right to housing is a public good that offers refugees and asylum seekers the opportunity to improve their selfreliance, participation and agency, which in turn, improves the quality of their lives. To afford them such opportunity, as has already been done by other countries, refugees and asylum seekers should receive differentiated treatment where housing is concerned.

This article therefore proposes that the South African government take the following measures as a prerequisite to dealing with refugee housing problems in a way that is sensitive to their socio-economic situations:

- Differentiated treatment needs to be accorded to refugees and asylum seekers with regard to housing, given that treating them the same as non-citizens (with temporary residence status) nullifies the right of refugees and asylum seekers to adequate housing. The required treatment should be understood as aiming to achieve substantive equality, which requires South Africa to consider the actual socioeconomic conditions of groups and individuals in ultimately achieving constitutional equality. ${ }^{11}$

- As is constitutionally inspired and infused, the Refugees Act should be harmonised with the housing laws and regulations to meet South Africa's international obligations to house refugees and alleviate their human suffering.

- Allocating houses to refugees and asylum seekers must be achieved though the government's refugee housing policy, implemented by local government, together with or under the guidance of national government - particularly, the Department of Human Settlement.

- Housing development programmes should be revised to include refugees and asylum seekers as defined beneficiaries of such programmes.

- Both the NHPSP and the National Housing Code should be rectified in line with the above-proposed revision of the housing development

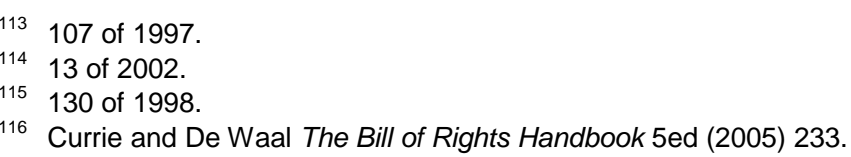


programmes. These policies should state that a refugee or an asylum seeker has the right to housing if he or she is recognised as such.

- A refugee housing policy should be established to determine the types of housing development programme to which refugees and asylum seekers respectively should have access. For example, whilst asylum seekers should be given an opportunity to have access to emergency shelter, refugees should benefit from other subsidised social housing. If unemployed, they should have access to emergency housing.

- There is a need to build emergency houses or shelter that would accommodate individuals who were displaced as a result of persecution or other events disrupting public order and who are in search of shelter in South Africa. They should therefore not be restricted to Processing Centres.

- South Africa should establish an entity or institution entrusted with: assessing the housing needs and social vulnerabilities of refugees and asylum seekers; managing their human settlement or housing; and more importantly, their integration into South African communities. The assessment should, in particular, identify or determine special protection needed by different categories of refugee and asylum seeker - more notably, by minors (separated or non-accompanied), people with disabilities, the elderly, the unemployed, people with serious diseases and mentally ill persons. To facilitate access to the different categories of subsidised housing, assessments in this regard should also be directed at determining the income levels of the different categories of refugee that is, employed, self-employed or unemployed. 